\title{
REPLACEMENT OF TIFTON 85 HAY WITH MANIÇOBA HAY IN THE SPINELESS CACTUS DIET OF SHEEP ${ }^{1}$
}

\author{
FRANCICLEIDE MARIA DE SOUZA CHARLL SANTOS ${ }^{2}$, DORGIVAL MORAIS DE LIMA JÚNIOR ${ }^{3 *}$, DANIEL \\ BARROS CARDOSO ${ }^{4}$, MICHEL DO VALE MACIEL ${ }^{5}$, FRANCISCO FERNANDO RAMOS DE CARVALHO ${ }^{2}$
}

\begin{abstract}
The objective of this study was to evaluate the effect of replacing Tifton 85 hay with maniçoba hay in diets based on spineless cactus on the nutrient intake and digestibility, ingestive behaviour and ruminal parameters of confined sheep. In order to do this, eight male sheep with ruminal cannulae were used, distributed across four levels $\left(0,333,666\right.$ and $1.000 \mathrm{~g} \mathrm{~kg}^{-1}$ of dry matter) of replacement of Tifton 85 hay with maniçoba hay in a double Latin square experimental design. The animals were confined for 60 days divided into four periods of 15 days. The replacement of Tifton 85 hay with maniçoba hay did not influence the dry matter intake or digestibility. However, it influenced in a positive linear fashion the intake of non-fibrous carbohydrates and in a linear negative fashion the digestibility of insoluble fibre in neutral detergent and crude protein. The ruminal ammonia-nitrogen and the crude protein ruminal content decreased linearly with the replacement of Tifton 85 hay with maniçoba hay. There was no effect of hay replacement on the production of volatile fatty acids or the microbial biofilm. The total replacement Tifton 85 by maniçoba hay in spineless cactus diets for sheep did not influence total digestible nutrient intake, volatile fatty acid production or biofilm, but did affect crude protein digestibility, ammonia-nitrogen and crude protein content in the rumen. Therefore, maniçoba hay can replace $300 \mathrm{~g} \mathrm{~kg}^{-1}$ grass hay in spineless cactus diets for sheep without compromising intake and ruminal parameters.
\end{abstract}

Keywords: Forage cactus. Manihot pseudoglaziovii. Nopalea. Ruminal parameters. Tropical shrub.

\section{SUBSTITUIÇÃO DO FENO DE TIFTON 85 POR FENO DE MANIÇOBA EM DIETAS A BASE DE PALMA FORRAGEIRA PARA OVINOS}

RESUMO - O objetivo deste estudo foi avaliar o efeito da substituição do feno de Tifton 85 pelo feno de maniçoba em dietas à base de palma forrageira sobre a ingestão e digestibilidade de nutrientes, comportamento ingestivo e parâmetros ruminais de ovinos confinados. Foram utilizados oito ovinos machos com cânula ruminal, distribuídos em quatro níveis $\left(0,333,666\right.$ e $1.000 \mathrm{~g} \mathrm{~kg}^{-1}$ de matéria seca) de substituição do feno de Tifton 85 por feno de maniçoba em delineamento quadrado latino. Os animais permaneceram confinados por 60 dias divididos em quatro períodos de 15 dias. A substituição do feno de Tifton 85 por feno de maniçoba não influenciou no consumo ou digestibilidade de matéria seca. No entanto, influenciou de forma linear negativa na digestibilidade da fibra insolúvel em detergente neutro e proteína bruta. $\mathrm{O}$ nitrogênio amoniacal e proteína bruta ruminal diminuiu linearmente com a substituição do feno de Tifton 85 por feno de maniçoba. Não houve efeito da substituição do feno na produção de ácidos graxos voláteis ou no biofilme microbiano. A substituição total de Tifton 85 por feno de maniçoba em rações de palma forrageira para ovinos não influenciou o consumo de nutrientes digestíveis totais, a produção de ácidos graxos voláteis ou biofilme, mas afetou a digestibilidade da proteína bruta, nitrogênio amoniacal e teor de proteína bruta no rúmen. Portanto, o feno de maniçoba pode substituir até $300 \mathrm{~g} \mathrm{~kg}^{-1}$ de feno de capim em dietas de palma forrageira para ovinos, sem comprometer o consumo e os parâmetros ruminais.

Palavras-chave: Cactácea forrageira. Manihot pseudoglaziovii. Nopalea. Parâmetros ruminais. Arbusto tropical.

\footnotetext{
${ }^{*}$ Corresponding author

${ }^{1}$ Received for publication in 12/06/2019; accepted in 08/28/2020.

${ }^{2}$ Department of Animal Science, Universidade Federal Rural de Pernambuco, Recife, PE, Brazil; francicleidecharll@yahoo.com - ORCID: 0000-0003-3209-0736, ffrcarvalho@hotmail.com - ORCID: 0000-0001-9211-0263.

${ }^{3}$ Universidade Federal de Alagoas, Arapiraca, AL, Brazil; juniorzootec@yahoo.com.br - ORCID: 0000-0002-1154-8579.

${ }^{4}$ Animal Science College, Universidade Federal do Agreste de Pernambuco, Garanhuns, PE, Brazil; danbarrc@hotmail.com - ORCID: 0000-0002-9460-1338.

${ }^{5}$ Universidade Federal do Amazonas, Parintins, AM, Brazil; micheldr_el@hotmail.com - ORCID: 0000-0001-8429-3063.
} 


\section{INTRODUCTION}

The increasing frequency of drought in the tropics on the planet has contributed to nutritional insecurity of ruminant herds in these regions (DARCAN, SILANIKOVE, 2018). Therefore, forage resources tolerant to water deficiency, such as spineless cactus, are important in the promotion of animal food security in tropical environments.

The spineless cactus is rich in non-fibrous carbohydrate (NFC) and has low levels of neutral detergent fibre (NDF) and lignin (SANTOS et al., 2018). These characteristics result in rapid and high ruminal degradability and extensive gas production (DEL RAZO et al., 2015), factors associated with the occurrence of bloat in spineless-cactus-exclusive diets (SANTOS et al., 2010). Therefore, it is essential to use a fibre source in association with the spineless cactus to avoid nutritional disorders that compromise animal performance (RAMOS et al., 2013).

Conserved or fresh grasses have been tested in association with spineless cactus by several authors (LIMA et al., 2018; CARDOSO et al., 2019). In summary, it is agreed that the presence of fibre from forage is essential to maintain a healthy ruminal environment. However, other forages besides grasses, such as hay or silage from trees and shrubs, contain fibre and can be used in diets in association with spineless cactus (WANDERLEY et al., 2012).

Seidavi et al. (2018), in an extensive review, highlighted the potential of trees and shrubs in ruminant feeds in tropical areas, mainly in the form of hay and silage. Therefore, preliminary studies with maniçoba (Manihot pseudoglaziovii Pax \& Hoffman), a tropical xerophyte shrub native to Brazil, indicated the good potential nutritive value of this feed for ruminants (LIMA JÚNIOR et al., 2015; SANTOS et al., 2017). However, due to their in vivo toxicity to the animals, the supply of hay or silage should be regulated (RAMOS et al., 2015). In semiarid zones native forages are used because of the difficulty of cultivating exotic grasses, which typically have high water demand and include Tifton or Bermuda grass (Cynodon spp.; LIMA JÚNIOR et al., 2014)

The objective of this study was to evaluate the effect of replacement of Tifton 85 hay with maniçoba hay in spineless cactus diets on the intake, ingestive behaviour, digestibility and ruminal parameters of confined sheep.

\section{MATERIALS AND METHODS}

All the procedures performed were authorised by the Ethics Committee on Animal Use, CEUA/
UFRPE (licence 078/2015).

The experiment was carried out in the Northeast region of Recife, Brazil. The city has an average temperature of $25.8 \pm 2.8{ }^{\circ} \mathrm{C}$ and rainfall of $18 \mathrm{~cm}$ year $^{-1}$.

Eight castrated male Santa Ines sheep, cannulated in the rumen, with a body weight of $53.17 \pm 8.33 \mathrm{~kg}$ were used in the study. The animals were housed in individual stalls measuring $2.00 \times$ $1.80 \mathrm{~m}$ located in an open shed with a cement floor and ceiling of $3.5 \mathrm{~m}^{2}$ covered with clay tiles. The shed was maintained under artificial lighting throughout the experimental period. Before starting the experiment, the animals were treated for parasites and received an injectable vitamin and mineral supplement.

The sheep were housed in the stalls for 60 days divided into four experimental periods, each with a duration of 15 days, which comprised 10 days of adaptation to the treatments and 5 days of data collection. The treatments consisted of increasing levels $\left(0 \mathrm{~g} \mathrm{~kg}{ }^{-1}, 333 \mathrm{~g} \mathrm{~kg}^{-1}, 666 \mathrm{~g} \mathrm{~kg}^{-1}\right.$ and $\left.1.000 \mathrm{~g} \mathrm{~kg}^{-1}\right)$ of replacement of Tifton 85 hay with maniçoba hay (Manihot pseudoglaziovii Pax \& Hoffman). The treatment-diets were distributed in a double Latin square experimental design $(4 \times 4)$, with eight animals and for four consecutive periods.

The experimental diets were formulated to meet the maintenance requirements of adult sheep weighing $55 \mathrm{~kg}$ (NRC, 2007) and composed of spineless cactus (Nopalea cochenillifera (L.) SalmDyck), Tifton 85 hay (Cynodon spp.), maniçoba hay (Manihot pseudoglaziovii Pax \& Hoffman), soybean meal, ground corn, mineral mix, and urea (Tables 1 and 2).

The maniçoba hay was made at the beginning of the rainy season in the city of São João do Cariri, Paraíba, Brazil (latitude: $7^{\circ} 23^{\prime} 27^{\prime \prime}$ south, longitude: $36^{\circ} 32^{\prime} 2^{\prime \prime}$ west). The plants were harvested directly from the native forest of the region. The plants were harvested manually, in the flowering phase and the beginning of fruiting, with leaves and stems up to $5 \mathrm{~cm}$ in circumference. The harvested material was cut in a forage machine and dried in the sun for approximately 3 days to obtain the hay. Subsequently, the hay was packed in polyethylene bags and stored in a shed on wooden pallets.

Before being fed to the animals, the maniçoba hay was again crushed in a forage machine with a $13 \mathrm{~mm}$ sieve. Tifton 85 hay was purchased locally and crushed using a $13 \mathrm{~mm}$ sieve. The corn and soybean meal were also crushed using a $4.5 \mathrm{~mm}$ sieve. The spineless cactus was cut in a forage machine, immediately before the tender, and mixed with the other ingredients of the diets, according to the treatment. 
Table 1. Chemical composition of the ingredients $\left(\mathrm{g} \mathrm{kg}^{-1}\right.$ of dry matter) used in the experimental diets.

\begin{tabular}{|c|c|c|c|c|c|}
\hline & Tifton 85 hay & Maniçoba hay & Spineless cactus & Ground corn & Soybean meal \\
\hline Dry Matter ${ }^{\#}$ & 898.1 & 895.8 & 72.3 & 853.7 & 865.8 \\
\hline Ash & 67.1 & 78.4 & 231.1 & 16.3 & 89.3 \\
\hline Crude protein & 57.1 & 90.8 & 76.0 & 92.9 & 486.9 \\
\hline NDFap $^{1}$ & 798.1 & 616.1 & 255.2 & 66.4 & 174.8 \\
\hline $\mathrm{ADF}^{2}$ & 386.2 & 462.7 & 154.8 & 19.2 & 81.4 \\
\hline Ether extract & 11.3 & 18.7 & 15.0 & 10.4 & 4.5 \\
\hline $\mathrm{NFC}^{3}$ & 25.9 & 124.1 & 387.6 & 784.5 & 59.8 \\
\hline NDIP $^{4}$ & 32.0 & 50.1 & 18.6 & 9.8 & 67.2 \\
\hline $\mathrm{ADIP}^{5}$ & 2.5 & 14.7 & 2.2 & 1.0 & 1.6 \\
\hline Lignin & 53.6 & 131.4 & 18.7 & 3.7 & 4.3 \\
\hline $\mathrm{ME}^{6^{*}}$ & 1.9 & 2.0 & 2.3 & 3.3 & 3.4 \\
\hline
\end{tabular}

${ }^{\#} \mathrm{~g} \mathrm{~kg}^{-1}$ fresh matter; ${ }^{1} \mathrm{NDFap}$ : neutral detergent fibre corrected for ash and nitrogenous compounds; ${ }^{2} \mathrm{ADF}$ : Acid detergent fibre; ${ }^{3} \mathrm{NFC}$ : Non-fibrous carbohydrates; ${ }^{4} \mathrm{NDIP}$ : neutral detergent insoluble protein; ${ }^{5}$ ADIP: acid detergent insoluble protein; ${ }^{6} \mathrm{EM}$ : Metabolisable energy, Mcal/kg dry matter (DM). ${ }^{*}$ Table-value (VALADARES FILHO et al., 2015).

Table 2. Proportion of ingredients and chemical composition of the experimental diets.

\begin{tabular}{|c|c|c|c|c|}
\hline & \multicolumn{4}{|c|}{ Replacement levels $\left(\mathrm{g} \mathrm{kg}^{-1}\right)$} \\
\hline & 0 & 333 & 666 & 1.000 \\
\hline Ground corn $\left(\mathrm{g} \mathrm{kg}^{-1} \mathrm{DM}\right)$ & 170 & 170 & 180 & 180 \\
\hline Soybean meal ( $\left.\mathrm{g} \mathrm{kg}^{-1} \mathrm{DM}\right)$ & 110 & 100 & 90 & 80 \\
\hline Spineless cactus $\left(\mathrm{g} \mathrm{kg}^{-1} \mathrm{DM}\right)$ & 400 & 410 & 410 & 420 \\
\hline Maniçoba hay ( $\left.\mathrm{g} \mathrm{kg}^{-1} \mathrm{DM}\right)$ & 0 & 100 & 200 & 300 \\
\hline Tifton 85 hay $\left(\mathrm{g} \mathrm{kg}^{-1} \mathrm{DM}\right)$ & 300 & 200 & 100 & 0 \\
\hline Mineral mix ${ }^{*}\left(\mathrm{~g} \mathrm{~kg}^{-1} \mathrm{DM}\right)$ & 10 & 10 & 10 & 10 \\
\hline \multirow[t]{2}{*}{ Urea $\left(\mathrm{g} \mathrm{kg}^{-1} \mathrm{DM}\right)$} & 10 & 10 & 10 & 10 \\
\hline & \multicolumn{4}{|c|}{ Chemical composition $\left(\mathrm{g} \mathrm{kg}^{-1} \mathrm{DM}\right)$} \\
\hline Dry matter ${ }^{\#}$ & 183.7 & 183.6 & 180.0 & 176.6 \\
\hline Ash & 134.6 & 137.2 & 137.6 & 140.1 \\
\hline Crude protein & 156.1 & 154.4 & 152.8 & 151.1 \\
\hline Ether extract & 11.7 & 12.5 & 13.3 & 14.2 \\
\hline NDFap $^{1}$ & 372.0 & 354.6 & 335.3 & 317.9 \\
\hline Acid detergent fibre & 190.0 & 198.4 & 205.4 & 213.8 \\
\hline Non-fibrous carbohydrates & 308.9 & 326.4 & 342.5 & 354.7 \\
\hline $\mathrm{NDIP}^{2}$ & 26.1 & 27.5 & 28.7 & 30.0 \\
\hline $\mathrm{ADIP}^{3}$ & 2.0 & 3.2 & 4.4 & 5.7 \\
\hline Lignin & 24.7 & 33.6 & 40.4 & 48.3 \\
\hline Total digestible nutrient & 643.4 & 637.8 & 637.1 & 629.4 \\
\hline $\mathrm{ME}^{4}$ & 2.3 & 2.3 & 2.3 & 2.3 \\
\hline
\end{tabular}

${ }^{\#} \mathrm{~g} \mathrm{~kg}^{-1}$ fresh matter; ${ }^{1} \mathrm{NDFap}$ : neutral detergent fibre corrected for ash and nitrogenous compounds; ${ }^{2} \mathrm{NDIP}$ : neutral detergent insoluble protein; ${ }^{3} \mathrm{ADIP}$ : acid detergent insoluble protein; ${ }^{4} \mathrm{EM}$ : Metabolisable energy, Mcal $/ \mathrm{kg}$ DM.

The diets were offered at will in the form of a complete mix, in two daily meals at 8:00 a.m. (60\%) and at 4:00 p.m. (40\%). The adjustment in the amount of feed provided was made according to the intake of the previous day, allowing for $15 \%$ leftovers. Water was available permanently to the animals.

Water intake $\left(\mathrm{g}\right.$ day $\left.^{-1}\right)$ was measured throughout the experimental period by subtracting the leftovers during the whole experimental period from the quantity supplied (water by drinking and water from feed), with the aid of waterers placed at the ends and the centre of the confinement shed. Water losses due to evaporation were also measured.

The voluntary intake of DM and dietary nutrients was calculated by the difference between 
the quantities offered and the leftovers from the previous day. During the period of the apparent digestibility test (days 1 to 3 of each experimental period) the ingredients that made up the diets, leftovers, and faeces were sampled and dried in a forced ventilation oven (Tecnal(C), TE-394/2) at $55^{\circ}$ $\mathrm{C}$ for $72 \mathrm{~h}$ and mixed to form a composite sample (homogenised and, after removal of a $10 \%$ aliquot, ground in a Willey-type knife mill (MarconiC), MA1340) using a $2 \mathrm{~mm}$ followed by a $1 \mathrm{~mm}$ sieve) for further laboratory analyses.

For the determination of DM (method, 934.01), ash (method, 942.05), crude protein (CP, method, 968.06), and ether extract (EE, method, 920.39), methods described by the AOAC (2000) were used. Neutral detergent fibre and acid detergent fibre (ADF) were determined according to Van Soest, Robertson and Lewis (1991), and corrections for the ash and protein content followed the methodology described by Licitra, Hernandez and Van Soest (1996) and Mertens (2002), respectively. For the quantification of total carbohydrates (TC), the equation used was: $100-(\% \mathrm{CP}+\% \mathrm{EE}+\%$ ash), and for the NFC content of the diet only, the equation used was $\mathrm{NFC}=100 \%-((\% \mathrm{CP}-\% \mathrm{CP}$ derived from urea $+\%$ urea $)+\% \mathrm{NDF}+\% \mathrm{EE}+\%$ ash; HALL, 2000). For the estimation of total digestible nutrients (TDN), the equation used was $\mathrm{TDN}=\mathrm{DCP}+\mathrm{DEE} * 2.25+\mathrm{DNFC}+$ DNDFap, where $\mathrm{DCP}=(\mathrm{CP}$ ingested $-\mathrm{CP}$ faeces $), \mathrm{DEE}=(\mathrm{EE}$ ingested $-\mathrm{EE}$ faeces $), \mathrm{DNFC}=(\mathrm{NFC}$ ingested NFC faeces), and DNDF = (NDFap ingested NDFap faeces). In order to determine the apparent digestibility of the nutrients, the faecal DM production (FDMP) using the indigestible acid detergent fibre (iADF) as an internal indicator, was estimated followed the methodology described by Casali et al. (2008).

The observations of the ingestive behaviour were performed on the first day of data collection for each experimental period. The observations were performed visually using the scanning method proposed by Martin and Bateson (1993), at 5-min intervals over $24 \mathrm{~h}$ (JOHNSON; COMBS, 1991). The behavioural variables observed were feeding, rumination and rest times. The intake and rumination rates as a function of the DM ( $\mathrm{g}$ of $\left.\mathrm{DM} \mathrm{h}^{-1}\right)$ and feeding and rumination time $\left(\mathrm{h} \mathrm{day}^{-1}\right)$ were calculated following the methodology described by Bürger et al. (2000), which used the equations: intake rate $=\mathrm{DM}$ intake/feed time $\left(\mathrm{g}\right.$ of $\left.\mathrm{DM} \mathrm{h} \mathrm{h}^{-1}\right)$; rumination rate $=\mathrm{DM}$ intake/rumination time $(\mathrm{g}$ of $\mathrm{DM} \mathrm{h}^{-1}$ ).

For the collection of ruminal fluid, samples of the ruminal contents were taken manually from four different locations in the rumen and homogenised. The collections were performed every $4 \mathrm{~h}$ after the morning meal on three consecutive days, from the
13 th to the 15 th day of each experimental period. After the ruminal content was removed, the material was filtered through four layers of cotton cloth. The solid part was returned to the rumen, and immediately the product of the filtrate, the ruminal fluid, was homogenised and the $\mathrm{pH}$ measured by a Handylab 1-SCHOTT digital potentiometer. After $\mathrm{pH}$ measurement, a $20 \mathrm{~mL}$ aliquot was packed in duplicate in plastic containers containing $1 \mathrm{~mL}$ of $6 \mathrm{~N}$ hydrochloric acid and duly identified. These samples were stored at $-20{ }^{\circ} \mathrm{C}$ for subsequent quantification of ammonia-nitrogen $\left(\mathrm{N}-\mathrm{NH}_{3}\right)$ and volatile fatty acids (VFAs). For the determination of $\mathrm{N}-\mathrm{NH}_{3}$, the samples were thawed at room temperature and centrifuged at $3000 \mathrm{rpm}$ at $4{ }^{\circ} \mathrm{C}$ for 15 min (FENNER, 1965). For the quantification of VFAs, the samples were thawed at room temperature and centrifuged at $15000 \mathrm{~g}$ at $4{ }^{\circ} \mathrm{C}$ for $60 \mathrm{~min}$. The samples were read on a GC-MASTER gas chromatograph, using the Carbowax $20 \mathrm{M}$ reference capillary chromatography column. Column temperature was fixed at $150{ }^{\circ} \mathrm{C}$ for a run time of 2 min. Injector and detector temperatures were 250 and $270{ }^{\circ} \mathrm{C}$, respectively. Gas flows were 30,300 , and $25 \mathrm{ml} \mathrm{min}{ }^{-1}$ for $\mathrm{He}$, air and $\mathrm{H}_{2}$, respectively. Isocaproic acid was used as an internal standard.

Four hours after the morning meal, digesta samples were taken manually from several locations in the rumen and homogenised. Immediately after this, ruminal contents were filtered through four layers of cotton cloth, the ruminal fluid homogenised and a $500 \mathrm{~mL}$ aliquot taken for the evaluation of nitrogen fractionation and biofilm production in the ruminal fluid (MIN et al., 2002).

The experimental design was that of two simultaneous $4 \times 4$ Latin square, according to the following model: Yijkl $=\mu+\mathrm{Di}+\mathrm{aj}+\mathrm{pk}+$ eijkl, where: $\mu=$ general mean, $\mathrm{Di}=$ fixed dietary effect, aj $=$ random effect of the animal, $\mathrm{pk}=$ random effect of the experimental period, $\varepsilon i j k l=$ experimental error. The variables studied were interpreted through analysis of variance and regression, using PROC GLM of SAS (Statistical Analysis System, 2002).

\section{RESULTS AND DISCUSSION}

The replacement of the Tifton 85 hay with maniçoba hay did not influence the DM intake (mean \pm standard deviation, $1.30 \pm 0.19 \mathrm{~kg} \mathrm{day}^{-1}$; $2.46 \pm 0.38 \mathrm{~g} \mathrm{~kg}^{-1}$ body weight $(\mathrm{BW})$, and $66.50 \pm$ $10.12 \mathrm{~g} \mathrm{~kg}^{-1} \mathrm{BW}^{0.75}$ ), indicating the potential of maniçoba hay - a drought resistant shrub - as a substitute for the hay grasses used in spineless cactus diets (Table 3). Ribeiro et al. (2017) also did not find an effect on DM intake from the type of bulk used in association with spineless cactus. 
Table 3. Nutrient intake by sheep fed with increasing levels of replacement of Tifton 85 hay with maniçoba hay (Manihot pseudoglaziovii Pax \& Hoffman).

\begin{tabular}{|c|c|c|c|c|c|c|c|}
\hline & \multicolumn{4}{|c|}{ Replacement levels $\left(\mathrm{g} \mathrm{kg}^{-1}\right)$} & \multirow{2}{*}{ SEM* } & \multicolumn{2}{|c|}{$P$-value } \\
\hline & 0 & 333 & 666 & 1.000 & & $\mathrm{~L}$ & Q \\
\hline \multicolumn{8}{|c|}{ Intake $\left(\mathrm{kg} \mathrm{day}^{-1}\right)$} \\
\hline Dry matter & 1.29 & 1.27 & 1.24 & 1.43 & 0.19 & $>0.05$ & $>0.05$ \\
\hline Organic matter & 1.10 & 1.08 & 1.06 & 1.23 & 0.16 & $>0.05$ & $>0.05$ \\
\hline Neutral detergent fibre & 0.47 & 0.46 & 0.43 & 0.50 & 0.08 & $>0.05$ & $>0.05$ \\
\hline Acid detergent fibre & 0.21 & 0.22 & 0.23 & 0.28 & 0.09 & $0.0021^{1}$ & $>0.05$ \\
\hline Crude protein & 0.22 & 0.21 & 0.20 & 0.22 & 0.03 & $>0.05$ & $>0.05$ \\
\hline Ether extract & 0.015 & 0.016 & 0.017 & 0.020 & 0.001 & $0.0016^{2}$ & $>0.05$ \\
\hline $\begin{array}{l}\text { Non-fibrous } \\
\text { carbohydrates }\end{array}$ & 0.45 & 0.44 & 0.46 & 0.54 & 0.07 & $0.0190^{3}$ & $>0.05$ \\
\hline $\begin{array}{c}\text { Total digestible } \\
\text { nutrients }\end{array}$ & 0.83 & 0.81 & 0.79 & 0.90 & 0.13 & $>0.05$ & $>0.05$ \\
\hline \multicolumn{8}{|l|}{ Water intake $\left(\mathrm{kg} \mathrm{day}^{-1}\right)$} \\
\hline From drink & 0.03 & 0.02 & 0.03 & 0.04 & 0.01 & $>0.05$ & $>0.05$ \\
\hline From feed & 6.71 & 6.29 & 6.11 & 6.89 & 1.13 & $>0.05$ & $>0.05$ \\
\hline
\end{tabular}

"SEM: standard error of the mean. ${ }^{1} \mathrm{y}=0.2202+0.0007 \mathrm{x}\left(\mathrm{r}^{2}=0.8488\right) ;{ }^{2} \mathrm{y}=0.015+0.0000502 \mathrm{x}\left(\mathrm{r}^{2}=0.824\right) ;{ }^{2} \mathrm{y}=0.4297+$ $0.0009 x\left(r^{2}=0.648\right)$.

Despite the decrease in the NDF content of the experimental diets $\left(372 \mathrm{~g} \mathrm{~kg}^{-1}\right.$ to $\left.317 \mathrm{~g} \mathrm{~kg}^{-1}\right)$, the NDF intake was not influenced by the treatments, presenting values of $460 \pm 70 \mathrm{~g} \mathrm{day}^{-1}$ or $0.9 \pm 0.1 \mathrm{~g} \mathrm{~kg}^{-1} \mathrm{BW}$. However, the intake of $\operatorname{ADF}\left(\mathrm{y}=0.2202+0.0007 \mathrm{x} ; \mathrm{r}^{2}=0.8488\right)$, EE $\left(\mathrm{y}=0.015+0.0000502 \mathrm{x} ; \mathrm{r}^{2}=0.824\right)$ and NFC $\left(\mathrm{y}=0.4297+0.0009 \mathrm{x} ; \mathrm{r}^{2}=0.648\right)$ increased linearly $(\mathrm{P}<0.05)$ with the replacement of Tifton 85 hay with maniçoba hay. The effects observed on the intake of ADF, NFC and EE with the replacement of Tifton 85 hay with maniçoba hay are related to the chemical composition of the hay itself. Maniçoba hay is richer in ADF $\left(462.7 \mathrm{~g} \mathrm{~kg}^{-1}\right.$ vs $\left.386.2 \mathrm{~g} \mathrm{~kg}^{-1}\right)$, NFC (124 $\mathrm{g} \mathrm{kg}^{-1}$ vs $\left.25 \mathrm{~g} \mathrm{~kg}^{-1}\right)$ and EE $\left(18.7 \mathrm{~g} \mathrm{~kg}^{-1}\right.$ vs $\left.11.3 \mathrm{~g} \mathrm{~kg}^{-1}\right)$ than Tifton hay; therefore, the fractions of $\mathrm{ADF}, \mathrm{NFC}$ and $\mathrm{EE}$ in the experimental diets increased with increasing levels of maniçoba hay. Maciel et al. (2019) also observed a higher intake of NFC and EE in sheep fed with maniçoba hay than those fed Tifton hay 85 .

The apparent digestibility of the DM $(0.68 \pm$ $\left.0.03 \mathrm{~g} \mathrm{~kg}^{-1}\right)$ and organic matter $\left(0.70 \pm 0.03 \mathrm{~g} \mathrm{~kg}^{-1}\right)$ in the diets was not influenced by the replacement of Tifton 85 with maniçoba hay. However, there was a linear decrease in the digestibility of NDF and CP with increasing levels of maniçoba hay (Table 4).

Table 4. Apparent nutrient digestibility by sheep fed with increasing levels of replacement of Tifton 85 hay with maniçoba hay (Manihot pseudoglaziovii Pax \& Hoffman).

\begin{tabular}{|c|c|c|c|c|c|c|c|}
\hline & \multicolumn{4}{|c|}{ Replacement levels $\left(\mathrm{g} \mathrm{kg}^{-1}\right)$} & \multirow{2}{*}{ SEM $^{*}$} & \multicolumn{2}{|c|}{$P$-value } \\
\hline & 0 & 333 & 666 & 1.000 & & $\mathrm{~L}$ & Q \\
\hline Dry matter $\left(\mathrm{g} \mathrm{kg}^{-1}\right)$ & 0.69 & 0.68 & 0.68 & 0.66 & 0.05 & $>0.05$ & $>0.05$ \\
\hline Organic matter $\left(\mathrm{g} \mathrm{kg}^{-1}\right)$ & 0.70 & 0.70 & 0.69 & 0.67 & 0.04 & $>0.05$ & $>0.05$ \\
\hline Neutral detergent fibre $\left(\mathrm{g} \mathrm{kg}^{-1}\right)$ & 0.57 & 0.55 & 0.52 & 0.47 & 0.04 & $<0.0001^{1}$ & $>0.05$ \\
\hline Crude protein $\left(\mathrm{g} \mathrm{kg}^{-1}\right)$ & 0.81 & 0.80 & 0.79 & 0.76 & 0.07 & $0.0010^{2}$ & $>0.05$ \\
\hline Ether extract $\left(\mathrm{g} \mathrm{kg}^{-1}\right)$ & 0.40 & 0.41 & 0.40 & 0.43 & 0.03 & $>0.05$ & $>0.05$ \\
\hline
\end{tabular}

*SEM: standard error of the mean. ${ }^{1} \mathrm{y}=57.17-0.0895 \mathrm{x}\left(\mathrm{r}^{2}=0.965\right){ }^{2} \mathrm{y}=0.8156-0.0466 \mathrm{x}\left(\mathrm{r}^{2}=0.898\right)$.

It is possible that the increase in lignin and acid detergent insoluble protein (ADIP), which increased $95 \%$ and $185 \%$, respectively, when maniçoba hay completely replaced Tifton hay, is associated with a reduction in the digestibility of the fibrous and protein fractions of the diet. Similarly,
Ramos et al. (2015) observed the lower digestibility of NDF and CP when maniçoba hay replaced sorghum silage in spineless-cactus-based diets.

The feeding time of the sheep was influenced in a quadratic way and was maximum with the replacement of $427.2 \mathrm{~g} \mathrm{~kg}^{-1}$ of Tifton 85 hay with 
maniçoba hay, whereas there was a positive linear increase in rumination time with the replacement of Tifton 85 hay with maniçoba hay in the diet (Table
5). The intake rate decreased linearly with when maniçoba hay replaced $425.0 \mathrm{~g} \mathrm{~kg}^{-1}$ of Tifton 85 hay in the diet.

Table 5. Ingestive behaviour of sheep fed with increasing levels of replacement of Tifton 85 hay with maniçoba hay (Manihot pseudoglaziovii Pax \& Hoffman).

\begin{tabular}{|c|c|c|c|c|c|c|c|}
\hline & \multicolumn{4}{|c|}{ Replacement levels $\left(\mathrm{g} \mathrm{kg}^{-1}\right)$} & \multirow{2}{*}{ SEM $^{*}$} & \multicolumn{2}{|c|}{$P$-value } \\
\hline & 0 & 333 & 666 & 1.000 & & $\mathrm{~L}$ & Q \\
\hline Feeding time $\left(\mathrm{min}\right.$ day $\left.^{-1}\right)$ & 178.5 & 216.9 & 183.1 & 172.5 & 27.04 & $>0.05$ & $0.0196^{1}$ \\
\hline Rumination time $\left(\min\right.$ day $\left.^{-1}\right)$ & 317.5 & 426.2 & 390.6 & 433.1 & 77.39 & $0.0199^{2}$ & $>0.05$ \\
\hline Rest time (min day $\left.{ }^{-1}\right)$ & 943.8 & 796.9 & 866.2 & 834.4 & 84.31 & $>0.05$ & $>0.05$ \\
\hline Intake rate $\left(\mathrm{g} \mathrm{DM} \mathrm{min}{ }^{-1}\right)$ & 7.66 & 6.15 & 6.82 & 8.34 & 1.35 & $>0.05$ & $0.0052^{3}$ \\
\hline Intake rate $\left(\mathrm{g} \mathrm{NDF} \mathrm{min}^{-1}\right)$ & 2.74 & 2.22 & 2.40 & 2.92 & 0.47 & $>0.05$ & $0.0058^{4}$ \\
\hline Rumination rate $\left(\mathrm{g} \mathrm{DM} \min ^{-1}\right)$ & 3.12 & 3.13 & 3.24 & 3.38 & 1.06 & $>0.05$ & $>0.05$ \\
\hline Rumination rate (g NDF $\min ^{-1}$ ) & 1.10 & 1.12 & 1.13 & 1.17 & 0.39 & $>0.05$ & $>0.05$ \\
\hline
\end{tabular}

*SEM: standard error of the mean. ${ }^{1} \mathrm{y}=183.39+0.9314 \mathrm{x}-0.0109 \mathrm{x}^{2}\left(\mathrm{r}^{2}=0.608\right) ;{ }^{2} \mathrm{y}=345.43+0.09337 \mathrm{x}\left(\mathrm{r}^{2}=0.704\right) ;{ }^{3} \mathrm{y}=$ $7.5888-0.0595 \mathrm{x}+0.0007 \mathrm{x}^{2}\left(\mathrm{r}^{2}=0.964\right) ;{ }^{4} \mathrm{y}=2.7205+0.0211 \mathrm{x}-0.0002 \mathrm{x}^{2}\left(\mathrm{r}^{2}=0.975\right)$.

The linear increase observed in sheep rumination time can be attributed to the lower effective rumen degradability $\left(2 \% \mathrm{~h}^{-1}\right)$ of the NDF of maniçoba hay $(38.3 \%$ effective rumen degradability; MENEZES et al., 2012) than Tifton 85 hay $(61.2 \%$ effective rumen degradability; MUNIZ et al., 2012). However, the addition of maniçoba hay did not affect intake rate or sheep rumination, indicating its suitability as a source of fibre in fodder spineless cactus diets.
There was a linear decrease in the concentration of ammonia-nitrogen in the sheep rumen and the ruminal $\mathrm{pH}$ was influenced in a quadratic way by the replacement of Tifton 85 hay with maniçoba hay (Table 6). However, the ruminal concentration of acetate $(258.35 \pm 103.78 \mu \mathrm{mol}$ $\left.\mathrm{mL}^{-1}\right)$, propionate $\left(31.45 \pm 8.58 \mu \mathrm{mol} \mathrm{mL} \mathrm{mL}^{-1}\right)$, and

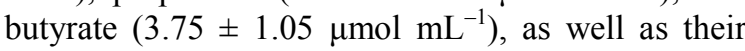
total, was not influenced by the treatments.

Table 6. Ruminal parameters of sheep fed with increasing levels of replacement of Tifton 85 hay with maniçoba hay (Manihot pseudoglaziovii Pax \& Hoffman).

\begin{tabular}{|c|c|c|c|c|c|c|c|}
\hline & \multicolumn{4}{|c|}{ Replacement levels $\left(\mathrm{g} \mathrm{kg}^{-1}\right)$} & \multirow{2}{*}{ SEM $^{*}$} & \multicolumn{2}{|c|}{$P$-value } \\
\hline & 0 & 333 & 666 & 1.000 & & $\mathrm{~L}$ & Q \\
\hline Ammonia-nitrogen $\left(\mathrm{mg} 100 \mathrm{~mL}^{-1}\right)$ & 23.1 & 19.9 & 19.6 & 18.7 & 11.01 & $0.0065^{1}$ & $>0.05$ \\
\hline $\mathrm{pH}$ & 6.7 & 6.8 & 6.7 & 6.7 & 0.30 & 0.0466 & $0.0292^{2}$ \\
\hline Total VFAs $\left(\mu \mathrm{mol} \mathrm{mL} L^{-1}\right)$ & 279.0 & 311.9 & 293.0 & 290.1 & 107.51 & $>0.05$ & $>0.05$ \\
\hline Acetate ( $\%$ molar $)$ & 87.0 & 87.2 & 86.5 & 87.2 & 3.54 & $>0.05$ & $>0.05$ \\
\hline Propionate (\% molar) & 11.4 & 11.6 & 12.1 & 11.4 & 3.05 & $>0.05$ & $>0.05$ \\
\hline Butyrate $(\%$ molar $)$ & 1.6 & 1.7 & 1.5 & 1.4 & 0.74 & $0.0283^{3}$ & $>0.05$ \\
\hline
\end{tabular}

*SEM: standard error of the mean; VFAs: volatile fatty acids. ${ }^{1} \mathrm{y}=23.772-1.3665 \mathrm{x}\left(\mathrm{r}^{2}=0.834\right) ;{ }^{2} \mathrm{y}=6.7044+0.0003 \mathrm{x}-$ $0.000007 \mathrm{x}^{2}\left(\mathrm{r}^{2}=0.625\right) ;{ }^{3} \mathrm{y}=1.6698-0.0024 \mathrm{x}\left(\mathrm{r}^{2}=0.642\right)$.

The presence of approximately $20 \mathrm{~g} \mathrm{~kg}^{-1}$ of total tannins in maniçoba hay (SANTOS et al., 2017) might have contributed to the reduction in protein digestibility of the diets. Min and Solaiman (2018) showed that tannins in the sheep diet consistently reduce $\mathrm{CP}$ digestibility and ruminal ammonia levels. In addition to the presence of total tannins, an increase in the insoluble nitrogen content and a reduction in the digestibility of the $\mathrm{CP}$ content of the diet are associated with a decrease in the 
concentration of ammonia-nitrogen in the rumen (PAULA et al., 2017).

Therefore, sheep fed increasing levels of maniçoba hay, which increased ADIP and reduced the digestible protein levels, demonstrated a linear decrease in ammonia-nitrogen levels. We also propose that the high carbohydrate content of the A + B1 fraction present in maniçoba hay, accounting for $400 \mathrm{~g} \mathrm{~kg}^{-1}$ of TC (SANTOS et al., 2017) compared to $180 \mathrm{~g} \mathrm{~kg}^{-1}$ of TC for Tifton hay (SUNAHARA et al., 2018), contributed to a greater mobilisation of ammonia-nitrogen, thus reducing its concentration in the rumen of sheep fed with higher levels of maniçoba.

The ruminal $\mathrm{pH}$ behaved in a quadratic way, with a maximum point when maniçoba hay was substituted aat $422.5 \mathrm{~g} \mathrm{~kg}^{-1}$ of Tifton 85 hay. This effect can be attributed to the differences in the NDF and NFC content of the hays and the impact of these components on the production of VFAs and rumination time. Lima et al. (2018) also found differences in the ruminal $\mathrm{pH}$ of sheep fed with decreasing levels of Tifton 85 hay in association with spineless cactus.

The production of VFAs, although not influenced by the treatments, was high (293.5 \pm $107.50 \mu \mathrm{mol} \mathrm{mL} \mathrm{m}^{-1}$ ), with an acetate predominance $(86.9 \pm 3.53 \mathrm{~mol} \%)$. We can explain the high production of VFAs and the high proportion of acetate as being due to the presence of spineless cactus in the diet. The spineless cactus has high ruminal degradability and a predominantly acetic fermentation (DEL RAZO et al., 2015).

Increasing the amount of Tifton 85 hay replaced with maniçoba hay did not influence ruminal biofilm production $\left(1.45 \pm 0.3 \mathrm{mg} \mathrm{mL}^{-1}\right)$, but increased linearly the ruminal DM content and reduced linearly the ruminal $\mathrm{CP}$ content (Table 7 ).

Table 7. Biofilm and nitrogen fractionation of the rumen of sheep fed with increasing levels of replacement of Tifton 85 hay with maniçoba hay (Manihot pseudoglaziovii Pax \& Hoffman).

\begin{tabular}{|c|c|c|c|c|c|c|c|}
\hline & \multicolumn{4}{|c|}{ Replacement levels $\left(\mathrm{g} \mathrm{kg}^{-1}\right)$} & \multirow{2}{*}{ SEM $^{*}$} & \multicolumn{2}{|c|}{$P$-value } \\
\hline & 0 & 333 & 666 & 1.000 & & $\mathrm{~L}$ & $\mathrm{Q}$ \\
\hline Biofilm (mg mL $\left.{ }^{-1}\right)$ & 1.6 & 1.3 & 1.4 & 1.5 & 0.03 & $>0.05$ & $>0.05$ \\
\hline \multicolumn{8}{|l|}{ Dry matter $\left(\mathrm{g} \mathrm{kg}^{-1}\right)$} \\
\hline Total content & 12.3 & 12.4 & 13.7 & 14.9 & 1.09 & $0.0001^{1}$ & $>0.05$ \\
\hline Fluid & 3.7 & 3.6 & 3.6 & 3.9 & 0.39 & $>0.05$ & $>0.05$ \\
\hline Solid content & 23.3 & 22.9 & 23.2 & 24.5 & 1.50 & $>0.05$ & $>0.05$ \\
\hline \multicolumn{8}{|c|}{ Crude protein $\left(\mathrm{g} \mathrm{kg}^{-1} \mathrm{DM}\right)$} \\
\hline Total content & 13.4 & 12.6 & 11.1 & 9.6 & 0.59 & $0.0001^{2}$ & $>0.05$ \\
\hline Fluid & 4.5 & 4.5 & 4.44 & 4.43 & 0.47 & $>0.05$ & $>0.05$ \\
\hline Solid content & 6.4 & 6.0 & 5.6 & 5.2 & 0.45 & $0.0002^{3}$ & $>0.05$ \\
\hline \multicolumn{8}{|c|}{$\mathrm{N}$ in the fluid $\left(\mathrm{mg} \mathrm{mL}^{-1}\right)$} \\
\hline Bacteria & 39.7 & 45.2 & 38.3 & 41.3 & 6.54 & $>0.05$ & $>0.05$ \\
\hline Protozoa & 173.4 & 178.3 & 188.0 & 178.1 & 3.36 & $>0.05$ & $>0.05$ \\
\hline Cell free liquid & 28.6 & 26.4 & 26.3 & 23.9 & 5.88 & $>0.05$ & $>0.05$ \\
\hline
\end{tabular}

*SEM: standard error of the mean. ${ }^{1} \mathrm{y}=11,964+0.0274 \mathrm{x}\left(\mathrm{r}^{2}=0.917\right) ;{ }^{2} \mathrm{y}=13,603+0.0388 \mathrm{x}\left(\mathrm{r}^{2}=0.983\right) ;{ }^{3} \mathrm{y}=-6.3976+$ $0.012 x\left(r^{2}=0.999\right)$.

Santos et al. (2010) also observed that the type of fibre - Tifton 85 hay or soybean hull - in association with spineless cactus did not influence the production of microbial biofilms. The replacement of Tifton 85 hay with maniçoba hay resulted in a linear increase in ruminal DM and a linear decrease in ruminal CP content. We propose that the reduction in the digestibility of NDF reduced the rate of passage of solids and, therefore, the DM content of the sheep rumen was high. Corroborating this, Souza et al. (2009) observed that the amount of ruminal DM was higher in diets with less soluble
NDF.

Given the decrease in rumen CP content with increasing levels of substitution of Tifton 85 hay with maniçoba hay, it is possible that the reduction in the digestibility of crude dietary protein reduced the $\mathrm{CP}$ synthesis of the microbial population and occasioned the reduction in rumen $\mathrm{CP}$ content. Xie et al. (2018), when evaluating high- and low-quality forages, verified that the $\mathrm{CP}$ digestibility of the diet interferes in the synthesis of ruminal microbial protein in sheep. 


\section{CONCLUSION}

The total replacement maniçoba hay by Tifton 85 hay in spineless cactus diets for sheep did not influence total digestible nutrient intake, volatile fatty acids production or biofilm, but did affect crude protein digestibility, ammonia-nitrogen and crude protein content in the rumen. Therefore, maniçoba hay can replace $300 \mathrm{~g} \mathrm{~kg}^{-1}$ grass hay in spineless cactus diets for sheep without compromising intake and ruminal parameters. Further studies would be needed to validate whether $100 \%$ replacement grass hay by shrub hay could be used in spineless cactus diets for performance sheep.

\section{REFERENCE}

ASSOCIATION OF OFFICIAL ANALYTICAL CHEMISTS - AOAC. Official Methods of Analysis, 15th ed. Arlington: AOAC International. 2000. 2200 p.

BÜRGER, P. J. et al. Comportamento ingestivo em bezerros holandeses alimentados com dietas contendo diferentes níveis de concentrado. Revista Brasileira de Zootecnia, 29: 236-242, 2000.

CARDOSO, D. B. et al. Levels of inclusion of spineless cactus (Nopalea cochenillifera Salm Dyck) in the diet of lambs. Animal Feed Science and Technology, 247: 23-31, 2019.

CASALI, A. O. et al. Influencia do tempo de incubação e do tamanho de partículas sobre os teores de compostos indigestíveis em alimentos e fezes bovinas obtidos por procedimentos in situ. Revista Brasileira de Zootecnia, 37: 335-342, 2008.

DARCAN, N. K.; SILANIKOVE, N. The advantages of goats for future adaptation to Climate Change: A conceptual overview. Small Ruminant Research, 163: 34-38, 2018.

DEL RAZO, O. E. et al. Comparative analysis of the in vitro fermentation of wasted cladodes (Opuntia spp.), lucerne and oat hays. South African Journal of Animal Science, 45: 470-475, 2015.

FENNER, H. Methods for determining total volatile bases in rumen fluid by steam distillation. Journal of Dairy Science, 48: 249-251, 1965.

HALL, M. B. Calculation of non-structural carbohydrate content of feeds that contain nonprotein nitrogen. 1. ed. Gainesville, FL: University of Florida, 2000. 25 p. (Bulletin, 339).
JOHNSON, T. R.; COMBS, D. K. Effects of prepartum diet, inert rumen bulk, and dietary polyethylene glycol on dry matter intake of lactating dairy cows. Journal of Dairy Science, 74: 933-944, 1991.

LICITRA, G., HERNANDEZ, T. M., VAN SOEST, P. J. Standardization of procedures for nitrogen fractionation of ruminant feed. Animal Feed Science and Technology, 57: 347-358, 1996.

LIMA, T. J. et al. Ruminal and morphometric parameters of the rumen and intestines of sheep fed with increasing levels of spineless cactus (Nopalea cochenillifera Salm-Dyck). Tropical Animal Health and Production, 51: 363-368, 2018.

LIMA JÚNIOR, D. M. et al. Componentes do peso corporal de ovinos morada nova alimentados com feno de maniçoba ou feno de Tifton. Revista Caatinga, 28: 239-246, 2015.

LIMA JÚNIOR, D. M. et al. Effect of the replacement of Tifton 85 with maniçoba hay on the performance of Morada Nova hair sheep. Tropical Animal Health and Production, 46: 995-1000, 2014.

MACIEL, M. V. et al. Maniçoba hay or silage replaces Tifton 85 hay in spineless cactus diets for sheep. Acta Scientiarum. Animal Sciences, 41: e42553, 2019.

MARTIN, P.; BATESON, P. Measuring behavior: an introductory guide. 3.ed. New York: Cambridge: University Press. 1993. 176 p.

MENEZES, D. R. et al. Cinética de degradação de frações nutricionais de euforbiáceas. Revista Brasileira de Saúde e Produção Animal, 13: 424432, 2012.

MERTENS, D. R. Gravimetric determination of amylase-treated neutral detergent fiber in feeds with refluxing in beaker or crucibles: collaborative study. Journal of AOAC International, 85: 1217-1240, 2002.

MIN, B. R.; SOLAIMAN, S. Comparative aspects of plant tannins on digestive physiology, nutrition and microbial community changes in sheep and goats: A review. Journal of Animal Physiology and Animal Nutrition, 102: 1181-1193, 2018.

MIN, B. R. et al. Lotus corniculatus condensed tannins decrease in vivo populations of proteolytic bacteria and affect nitrogen metabolism in the rumen of sheep. Canadian Journal of Microbiology, 48: 911-21, 2002. 
MUNIZ, E. B. et al. Cinética ruminal da fração fibrosa de volumosos para ruminantes. Revista Ciência Agronômica, 43: 604-610, 2012.

NATIONAL RESEARCH COUNCIL - NRC. Nutrient Requirements of Small Ruminants: Sheep, Goats, Cervids, and New World Camelids. 1.ed. Washington, D.C.: National Academy Press, 2007. 384 p.

PAULA, E. M. et al. Effects of replacing soybean meal with canola meal differing in rumenundegradable protein content on ruminal fermentation and gas production kinetics using 2 in vitro systems. Journal of Dairy Science, 100: 1-12, 2017.

RAMOS, A. O. et al. Associação de palma forrageira com feno de maniçoba ou silagem de sorgo e duas proporções de concentrado na dieta de vacas em lactação. Arquivo Brasileiro de Medicina Veterinária e Zootecnia, 67: 189-197, 2015.

RAMOS, A. O. et al. Diferentes fontes de fibra em dietas a base de palma forrageira na alimentação de ovinos. Revista Brasileira de Saúde e Produção Animal, 14: 648-659, 2013.

RIBEIRO, J. S. et al. Spineless cactus associated with Tifton hay or sugarcane bagasse may replace corn silage in sheep diets. Tropical Animal Health and Production, 49: 995-1000, 2017.

SANTOS, A. O. A. et al. Effects of Bermudagrass hay and soybean hulls inclusion on performance of sheep fed cactus-based diets. Tropical Animal Health and Production, 42: 487-494, 2010.

SANTOS, R. D. et al. Divergence in nutrient concentration, in vitro degradation and gas production potential of spineless cactus genotypes selected for insect resistance. The Journal of Agricultural Science, 156: 450-456, 2018.

SANTOS, K. C. et al. Nutritional potential of forage species found in Brazilian Semiarid region. Livestock Science, 195: 118-124, 2017.

SEIDAVI, A. et al. Application of some trees/shrubs in ruminant feeding: a review. Agroforest Systems, 1: 1-12, 2018.

SOUZA, E. J. et al. Effects of soybean hulls inclusion on intake, total tract nutrient utilization and ruminal fermentation of goats fed spineless cactos (Opuntia ficus-indica Mill) based diets. Small Ruminant Research, 85: 63-69, 2009.
STATISTICAL ANALYSIS SYSTEM - SAS. SAS/

STAT User's Guide: version 8. 6. ed, Cary, NC, SAS Institute. 2002. 112 p.

SUNAHARA, S. M. M., et al. Fractionation of carbohydrates and proteins in tifton 85 bermudagrass hay at different cutting levels and storage time. Bioscience Journal, 34: 1663-1673, 2018.

VALADARES FILHO, S. C. et al. Tabelas Brasileiras de Composição de Alimentos para Ruminantes. $1^{\text {a }}$ ed. Viçosa, MG: Editora UFV, 2015. 473 p.

VAN SOEST, P. J.; ROBERTSON, J. B.; LEWIS, B. A. Methods for dietary fiber, neutral detergent fiber, and non starch polysaccharides in relation to animal nutrition. Journal of Dairy Science, 74: 3583-3597, 1991.

WANDERLEY, W. L. et al. Consumo, digestibilidade e parâmetros ruminais em ovinos recebendo silagens e fenos em associação à palma forrageira. Revista Brasileira de Saúde e Produção Animal, 13: 444-456, 2012.

XIE, X. et al. Effect of changing forage on the dynamic variation in rumen fermentation in sheep. Animal Science Journal, 89: 122-131, 2018. 